\title{
Short Communication: The presence of extended-spectrum beta-lactamase (ESBL) producing Escherichia coli on layer chicken farms in Blitar Area, Indonesia
}

\author{
FRESHINTA JELLIA WIBISONO ${ }^{1}$, BAMBANG SUMIARTO ${ }^{2}$, TRI UNTARI ${ }^{3}$, \\ MUSTOFA HELMI EFFENDI ${ }^{4,5, \vartheta}$, DIAN AYU PERMATASARI ${ }^{5}$, ADIANA MUTAMSARI WITANINGRUM ${ }^{5}$ \\ ${ }^{1}$ Doctoral Program in Veterinary Science, Faculty of Veterinary Medicine, Universitas Gadjah Mada. Jl. Fauna No. 2, Karangmalang, Yogyakarta 55281, \\ Indonesia \\ ${ }^{2}$ Department of Veterinary Public Health, Faculty of Veterinary Medicine, Universitas Gadjah Mada. Jl. Fauna No. 2, Karangmalang, Yogyakarta 55281, \\ Indonesia \\ ${ }^{3}$ Department of Microbiology, Faculty of Veterinary Medicine, Universitas Gadjah Mada. Jl. Fauna No. 2, Karangmalang, Sleman55281, Yogyakarta, \\ Indonesia \\ ${ }^{4}$ Halal Research Center, Universitas Airlangga. Jl. Raya Mulyorejo, Surabaya 60115, East Java, Indonesia. Tel./fax.: +62-31-5915551, \\ •email: mheffendi@yahoo.com \\ ${ }^{5}$ Department of Veterinary Public Health, Faculty of Veterinary Medicine, Universitas Airlangga. Jl. Raya Mulyorejo, Surabaya 60115, East Java, Indonesia
}

Manuscript received: 21 January 2020. Revision accepted: 19 May 2020.

\begin{abstract}
Wibisono FJ, Sumiarto B, Untari T, Effendi MH, Permatasari DA, Witaningrum AM. 2020. Short Communication: The presence of extended-spectrum beta-lactamase (ESBL) producing Escherichia coli on layer chicken farms in Blitar Area, Indonesia. Biodiversitas 21: 2667-2671. This study was aimed to determine the incidence of Extended-Spectrum Beta-Lactamase (ESBL) producing Escherichia coli on layer chicken in Blitar area. This was a cross-sectional study with a total of 205 cloacal swabs of layer chicken taken randomly. The sample was in isolation identification on MacConkey media and ESBL confirmation test produced by Escherichia coli was then carried out by the Double Disc Synergy Test (DDST) method and the VITEK® 2 Compact Automated System method. This study showed that $185(90.24 \%)$ isolates of positive Escherichia coli from a total of 205 samples of cloacal swabs of the layer chicken. The incidence of ESBL-producing Escherichia coli in cloacal swabs on layer chicken with the Double Disc Synergy Test (DDST) method and the VITEK ${ }^{\circledR} 2$ compact automatic method was 13 (7.03\%). Results in this study indicated that layer chicken has potential as reservoir for spreading ESBL to public health and needs strict hygienic measures to prevent their transmission to humans.
\end{abstract}

Keywords: Cloacal swab, Escherichia coli, ESBL, DDST, layer chicken, VITEK®2

\section{INTRODUCTION}

Use of antibiotics in the animal sector reaches around $80 \%$, mostly to increase growth in healthy animals (WHO 2017). Antibiotic residue cases in poultry products in Indonesia are found in several regions with different types of antibiotics and ranged between 8 to $70 \%$ (Etikaningrum and Iwantoro 2017). Bacterial resistance to poultry antibiotics is a major problem in the Indonesian poultry industry (Niasono et al. 2019). The speed of discovery of new types of antibiotics is slower than the speed of increased antibiotic resistance which causes concern that one day there will be no effective antibiotics available for the treatment of resistant bacterial infections (Handayani et al. 2017). This potential is an important vigilance point for public animals as well as human health.

Beta-lactam, tetracycline, and thylosine are antibiotics that are often used in some poultry farms (Mehdi et al. 2018; Niasono et al. 2019). There is a general farmers' perception that the use of antibiotics as a preventive measure at a low cost, has no side effects and it increases the high use of penicillin preparations on farms (Memish et al. 2004). Increased bacterial resistance to antibiotics in general causes ineffective treatment of infectious diseases due to which infection continues and increases the risk of spreading infection to others (WHO 2017; Yusha'u and Umar 2016).

Infection involving the ESBL is an epidemic that worsens the infection of other diseases (Santos et al. 2013). The finding of an ESBL-producing bacterium of $14.84 \%$ in processed animal products is a matter of public health involving the environment as a source of spread of resistant bacteria (ESBL) for human and animal health (Niasono et al. 2019; Yusha'u and Umar 2016). The presence of ESBLproducing Escherichia coli in poultry in Indonesia has been reported in broiler feces in chicken slaughterhouses in Bogor with molecular detection (genotypic) examination using PCR of 6\% (Lukman et al. 2016), and clinical microbiology (phenotypic) examination with an antibiotic sensitivity test method of $25 \%$ (Masruroh et al. 2016). In East Java, little is known about the ESBL cases from layer chicken farms and its distribution. Therefore, the aim of this study was to detect the ESBL producing E. coli isolated from cloacal swab of layer chicken samples in Blitar area in East Java, Indonesia and to understand the strains distribution. 


\section{MATERIALS AND METHODS}

\section{Research design, location, and sampling}

This cross-sectional study was conducted between March and May 2019, using total sample of 205 cloacal swabs of layer chicken. Samples were taken randomly from layer chicken in Blitar District, East Java, Indonesia, and consisted of 5 sub-districts and 41 farms (Table 2). Samples were included in Amies Swab transport media and stored in a cooler box before being taken to the laboratory (Seni et al. 2016). Sample preparation and further examination were carried out as soon as possible after sampling.

\section{Isolation and identification of Escherichia coli}

The cloacal swab in the Viscosa (Deltalab, Spain) Amies Swab transport medium at cold temperatures were brought to the laboratory for the isolation of $E$. coli bacteria (Effendi 2018; Putra et al. 2019). Samples of cloacal swabs of layer chicken were cultured on selective MacConkey Agar media no. 3 (Oxoid, England) incubated at $35-37^{\circ} \mathrm{C}$ for 20-24 hrs. The pure colony of E. coli was identified by the Gram staining test, then biochemical identification of bacteria was carried out by the IMVIC test (Indol-Motility, Methyl Red, Voges Proskauer, Citrate) and TSIA (Triple Sugar Iron Agar).

\section{Double Disc Synergy Test (DDST) for ESBL confirmation test}

ESBL producing $E$. coli can be confirmed using a confirmation test by Double Disc Synergy Test (DDST). This confirmation test was carried out to evaluate the presence of an inhibitory zone of ESBL activity with clavulanic acid. This conventional method was carried out using the Kirby-Bauer disk diffusion method on MuellerHinton agar (Merck, Germany). The DDST confirmation test used an antibiotic (Oxoid, England) disc Amoxicillinclavulanate $30 \mu \mathrm{g}$, Cefotaxim $30 \mu \mathrm{g}$, Ceftazidime $30 \mu \mathrm{g}$, and

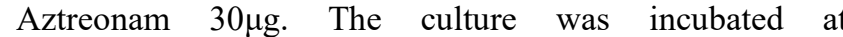
temperatures of $35-37^{\circ} \mathrm{C}$ for $18-24 \mathrm{hrs}$ (CLSI 2017; Effendi et al. 2019). Evaluation results after incubation showed the presence of inhibitory zones that appeared in the cup were measured according to the Clinical and Laboratory Standards Institute (CLSI) guidelines as shown in Table 1.

\section{VITEK@2 compact method of antibiotic sensitivity test}

Inoculated isolates were selected from a single colony. Gram-negative isolates used the VITEK ${ }^{\circledR} 2$ GN card. The isolates of this study used were pure E. coli isolates from cloacal swabs of layer chicken. The results were analyzed automatically by the system and interpreted as sensitive, intermediate, and resistant (Biomerieux 2017).

\section{RESULTS AND DISCUSSION}

\section{Isolation and identification of Escherichia coli}

The results of isolation and identification of 205 samples of cloacal swabs on layer chicken farms showed that $185(90.24 \%)$ isolates were positive for E. coli (Table 2). Positive samples of E. coli on MacConkey Agar were identified with reddish-pink colonies (Figure 1), then confirmed by biochemical tests using IMVIC and TSIA. MacConkey media we used for rapid identification of enteric bacteria. The presence of crystal violet and bile salts in the MacConkey selective media in order to inhibit Gram-positive growth, so MacConkey media is used to grow Gram-negative bacteria (Anggraini et al. 2018; Estiningsih et al. 2016). The IMVIC test was used to distinguish $E$. coli in its biochemical activity with other coliform bacteria (Leboffe and Pierce 2011). IMVIC test showed a motile result, Indol positive red ring formed after Kovac's reagent was added, Methyl Red (MR) test was positively indicated by a red color change, VogesProskauer (VP) test was negative with no color change, Citrate negative test was confirmed with color the media remains green and no change (Figure 2). The TSIA test produced gas, the upright and sloping media were yellow and there was no $\mathrm{H}_{2} \mathrm{~S}$ at the bottom of the tube (Figure 2). The results of isolation and identification of positive E. coli isolates from this study were in accordance with the standard microbiological literature on morphology and biochemical tests of $E$. coli bacteria (Brooks et al. 2013).

Table 1. ESBL producing Escherichia coli on Recommendation disc CLSI (CLSI 2017)

\begin{tabular}{lll}
\hline \multicolumn{2}{c}{ Antibiotic disc } & Inhibition zone on ESBL \\
\hline Cefotaxime & CTX $30 \mu \mathrm{g}$ & Inhibition Zone $\leq 27 \mathrm{~mm}$ \\
Ceftazidime & CAZ $30 \mu \mathrm{g}$ & Inhibition Zone $\leq 22 \mathrm{~mm}$ \\
Cefpodoxime & PX $10 \mu \mathrm{g}$ & Inhibition Zone $\leq 22 \mathrm{~mm}$ \\
Ceftriaxone & CRO $30 \mu \mathrm{g}$ & Inhibition Zone $\leq 25 \mathrm{~mm}$ \\
Aztreonam & ATM $30 \mu \mathrm{g}$ & Inhibition Zone $\leq 27 \mathrm{~mm}$ \\
\hline
\end{tabular}

Table 2. Data of ESBL producing Escherichia coli on this study

\begin{tabular}{|c|c|c|c|c|c|c|c|c|}
\hline \multirow{2}{*}{ Location } & \multirow{2}{*}{ Farms } & \multirow{2}{*}{ Sample size } & \multicolumn{2}{|c|}{ Escherichia coli } & \multicolumn{2}{|c|}{ ESBL (DDST) } & \multicolumn{2}{|c|}{ ESBL (VITEK) } \\
\hline & & & Positive & Percentage & Positive & Percentage & Positive & Percentage \\
\hline Ponggok & 10 & 50 & 45 & $90 \%$ & 1 & $2.22 \%$ & 1 & $100 \%$ \\
\hline Srengat & 17 & 85 & 77 & $90.5 \%$ & 8 & $10.39 \%$ & 8 & $100 \%$ \\
\hline Udanawu & 6 & 30 & 27 & $90 \%$ & 0 & 0 & 0 & $100 \%$ \\
\hline Talun & 4 & 20 & 17 & $85 \%$ & 1 & $5.88 \%$ & 1 & $100 \%$ \\
\hline Kademangan & 4 & 20 & 19 & $95 \%$ & 3 & $15.79 \%$ & 3 & $100 \%$ \\
\hline Total in Blitar area & 41 & 205 & 185 & $\begin{array}{c}90.24 \% \\
(185 / 205)\end{array}$ & 13 & $\begin{array}{c}7.03 \% \\
(13 / 185)\end{array}$ & 13 & $\begin{array}{c}100 \% \\
(13 / 13)\end{array}$ \\
\hline
\end{tabular}




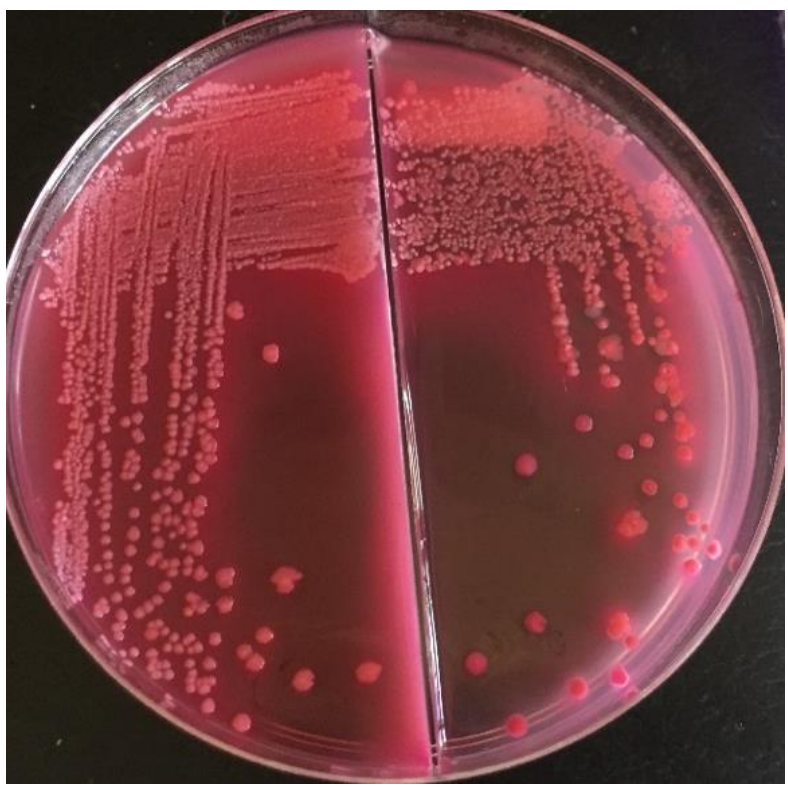

Figure 1. Escherichia coli on MacConkey Agar

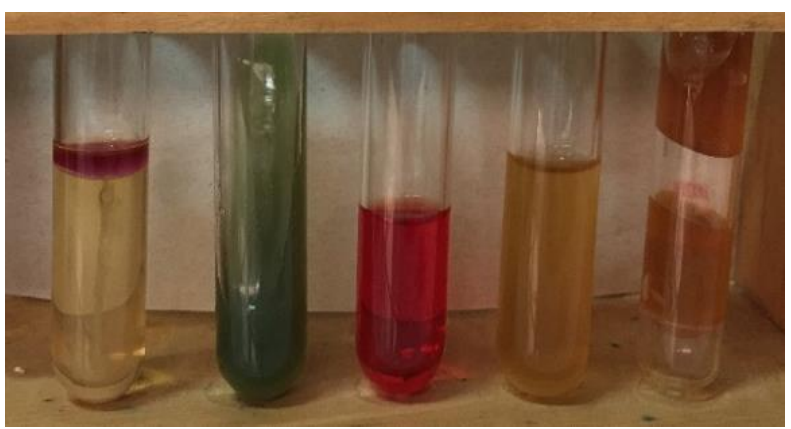

Figure 2. Identification Escherichia coli by IMVIC and TSIA

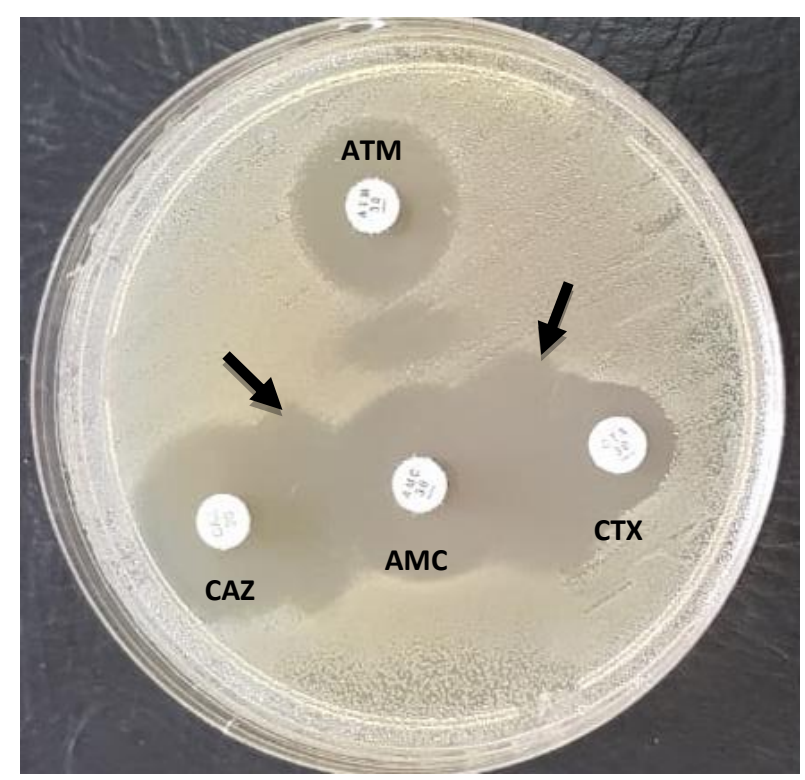

Figure 3. Confirmation ESBL producing Escherichia coli by Double Disc Synergy Test (DDST). Information: Cefotaxime (CTX ); Ceftazidime (CAZ); Amoxicillin-clavulanate (AMC); Aztreonam (ATM); black arrow is synergy formed.

\section{Double Disc Synergy Test (DDST) for ESBL confirmation test}

The results of this study showed the incidence of ESBL producing $E$. coli in cloacal swabs in layer chicken with the Double Disc Synergy Test (DDST) method of 13 (7.03\%) ESBL positive isolates (Table 2) and shown on Figure 3. The cefotaxime synergy with the combination of amoxicillin-clavulanate in the form of expansion of the barrier zone between the two disks showed that the bacteria were positive ESBL, this result was in accordance with Savira's statement ESBL. Positive results for ESBLproducing bacteria confirmed that there was an increase in the inhibition zone $\geq 5 \mathrm{~mm}$ between the diameter of the cephalosporin disk and the cephalosporin-clavulanate combination disk expressing positive ESBL germs (CLSI 2017; Savira 2014).

\section{The VITEK®2 compact method of antibiotic sensitivity test}

Positive isolate of ESBL-producing E. coli using the DDST method was then confirmed by the VITEK $®$ compact 2 methods to identify and test antibiotic sensitivity to the third cephalosporin group. The results of the identification of the Vitek method showed 100\% (13) positive isolates of $E$. coli and their sensitivity test showed $100 \%$ (13) ESBL producing isolates (Table 2). These results were consistent with the statement that the accuracy of VITEK® 2 compact automated system ranges from 97.8\% (O’Hara 2005) to 98.02\% (Duggal et al. 2012).

The results showed that the ESBL confirmation test with the DDST conventional method had the same incidence with the confirmation test using the VITEK® 2 compact method. The confirmation method of ESBLproducing $E$. coli in a conventional manner with the DDST method was more often used because it did not require analytical equipment at an expensive price and the cost of testing is relatively cheaper than the confirmation test using the VITEK® 2 compact method (Biomerieux 2017).

\section{Discussion}

In this study, ESBL-producing $E$. coli isolated from cloacal swab layer chicken samples from 41 layer chicken farms in Blitar area, Indonesia. Of the 41 layer chicken farms, almost of ESBL producing $E$. coli was detected in cloacal swab samples, which showed the possibility of the ESBL producer transmission route from food-producing animal farms (Gundogan and Avci 2013).

Escherichia coli as a commensal bacterium is commonly used as an indicator in surveillance and monitoring antibiotic resistance programs, because it is a gram-negative bacterium that is often found in animal feces and is associated with treatment in humans and often found conjugate plasmids that can move between enteric bacteria. $E$. coli as a reservoir of genes that have been resistant to antibiotics that can be transferred to other pathogenic bacteria (OIE 2015). The presence of commensal E. coli in the gut of livestock acts as a reservoir of resistant genes that can move horizontally to pathogenic E. coli and other bacteria in the food chain (Biutifasari 2018). This study was related with the incidence of ESBL producing E. coli 
in accordance with its incidence in broiler chicken feces in Bogor by $6 \%$ (Lukman et al. 2016), but much smaller than the incidence of ESBL producing $E$. coli in India layer chicken which is around $42 \%$ (Brower et al. 2017). Infections involving ESBL become an outbreak that exacerbates the infection of other diseases (Santos et al. 2013).

The occurrence of antibiotic resistance in layer chickens with a fairly high prevalence rate causes large economic losses for farmers (Etikaningrum and Iwantoro 2017). Antibiotic resistance causes a high economic burden on the human and animal health sector. Rational therapy, government regulation, public education are important points in the strategy of handling resistance problems (Utami 2011; Putra et al. 2020). Approaches to deal with antibiotic resistance in the form of policies such as the development and dissemination of technical guidelines, but these guidelines are usually cut off from the context of animal husbandry without considering the complexity of the problems of day-to-day farming practices and are therefore ignored by farmers (Bellet 2018). ESBLproducing bacteria are increasingly reported to contaminate water and mud (Blaak et al. 2014; Laube et al. 2014). Farms that use contaminated water can be a possible route for ESBL-producing $E$. coli to enter the food chain (Reinthaler et al. 2010; Zheng et al. 2012). In the past, ESBL-producing E. coli was also isolated from river water and mud samples, which had the same resistance profile and ESBL gene as stool isolates in the same water. These results indicated the potential influence of chicken farming as a reservoir for spreading ESBL producing $E$. coli to the surrounding water environment (Laube et al. 2014; Overdevest et al. 2011).

In the production of food-producing animals, especially the chicken layer, high concentrations of microorganisms in the air often occur in the environment in cages (Shoaib et al. 2016). These microorganisms in such cages can survive in the form of aerosols for a long time in the air and transmitted via airflow (Gao et al. 2015). In this study, ESBL-producing E. coli was obtained from cloacal swab samples, the isolates from the samples showed high similarities, which showed $E$. coli transmission that produced in the environment at the backyard poultry farm (Kwoji et al. 2019). Previous research has shown the spread of ESBL-producing $E$. coli originating from surrounding area (Canton et al. 2008). The concentration of microorganisms is closely related to sanitation quality. Poor sanitation can benefit the spread of ESBL-producing E. coli (Saliu et al. 2012).

In conclusion, This study confirms the presence of ESBL products $E$. coli on layer chicken farms in the Blitar area. This isolate also showed high levels of antibiotic resistance to third-generation cephalosporins. These results are very important for public health awareness since layer chicken maintained close to the human population and can spread this resistant pathogen through the environment and farmers who are close to the cage for the maintenance of these layer chicken.

\section{ACKNOWLEDGEMENTS}

We would like to express our heartfelt thanks to Rector of Airlangga University for providing funding for this study by Hibah Mandat Universitas Airlangga. We also would like to thank the Animal Husbandry Services of Blitar District for the collaboration during the recruitment process and provided surveillance data. This study was supported by grants Hibah Mandat with number: 371/UN3.14/LT/2019 from the Universitas Airlangga.

\section{REFERENCES}

Anggraini D, Hasanah U, Savira M, Andrini F, Irawan D, Prima R. 2018. Prevalence and susceptibility profile of ESBL-producing Enterobacteriaceae in Arifin Achmad General Hospital Pekanbaru. Jurnal Kedokteran Brawijaya 30: 47-52.

Bellet C. 2018. Drug resistance and the dynamics of livestock farm practices. J Rural Stud 63: 57-64.

Biomerieux. 2017. AST and Resistance Detection, Antibiotic Suceptibility Testing bioMérieux Industry website. www.biomerieuxdiagnostics.com

Biutifasari V. 2018. Extended spectrum beta-lactamase (ESBL). Oceana Biomed J 1: 1-6.

Blaak H, Kruijf P De, Hamidjaja RA, Hoek AHAM Van, Maria A, Husman DR, Schets FM. 2014. Prevalence and characteristics of ESBL-producing E. coli in Dutch recreational waters influenced by wastewater treatment plants. Vet Microbiol 7: 448-459.

Brooks GF, Carroll KC, Butel J, Morse SA, Mietzner T. 2013. Medical Microbiology, 26th ed. Mc Graw Hill, New York, USA.

Brower CH, Mandal S, Hayer S, Sran M, Zehra A, Patel SJ, Kaur R, Chatterjee L, Mishra S, Das BR, Singh P, Singh R, Gill JPS, Laxminarayan R. 2017. The prevalence of extended-spectrum betalactamase-producing multidrug-resistant Escherichia coli in poultry chickens and variation according to farming practices in Punjab, India. Environ Health Perspect 125: 1-10.

Canton R, Novais A, Valverde A, Machado E, Peixe L, Baquero F, Coque TM. 2008. Prevalence and spread of extended spectrum beta lactamase-producing Enterobacteriaceae in Europe. Clin Microbiol Rev 14: 144-153.

CLSI. 2017. M100 Performance Standards for Antimicrobial, 27th ed. Clinical and Laboratory Standards Institute, USA.

Duggal S, Gaind R, Tandon N, Deb M, Chugh T Das. 2012. Comparison of an automated system with conventional identification and antimicrobial susceptibility testing. Intl Scholarly Res Notices Microbiol 2012: 107203. DOI: 10.5402/2012/107203.

Effendi MH, Harijani N, Budiarto, Triningtya NP, Tyasningsih W, Plumeriastuti H. 2019. Prevalence of pathogenic Escherichia coli isolated from subclinical mastitis in East Java Province, Indonesia. Indian Vet J 96: 22-25.

Effendi MH, Harijani N, Yanestria SM. Hastutiek P. 2018. Identification of shiga toxin-producing Escherichia coli in raw milk samples from dairy cows in Surabaya, Indonesia. Philippine J Vet Med 55: 109-114.

Estiningsih D, Puspitasari I, Nuryastuti T. 2016. Identification of multidrug resistant organisms infection in Neonatal Intensive Care Unit (UNIT). Jurnal Manajemen dan Pelayanan Farmasi 6: 243-248.

Etikaningrum, Iwantoro S. 2017. Study of antibiotic residues in poultry products in Indonesia. Jurnal Ilmu Produksi dan Teknologi Hasil Peternakan 05: 29-33.

Gao L, Tan Y, Zhang X, Hu J, Miao Z. 2015. Emissions of Escherichia coli carrying extended-spectrum $\beta$-lactamase resistance from pig farms to the surrounding environment. Intl $\mathrm{J}$ Environ Res Public Health 12: 4203-4213.

Gundogan N, Avci E. 2013. Prevalence and antibiotic resistance of extended-spectrum beta-lactamase (ESBL) producing Escherichia coli and Klebsiella species isolated from foods of animal origin in Turkey. Afr J Microbiol Res 7: 4059-4064.

Handayani RS, Siahaan S, Herman MJ. 2017. Antimicrobial resistance and implementation of control policies in hospitals in Indonesia. Jurnal Penelitian dan Pengembangan Pelayanan Kesehatan 1: 131140 . 
Kwoji ID, Musa JA, Daniel N, Mohzo DL, Bitrus AA. 2019. Extended spectrum beta-lactamase-producing Escherichia coli in chickens from small-scale (backyard) poultry farms in Maiduguri, Nigeria. Intl J One Health 5: 26-30

Laube H, Friese A, Guerra B, Ro U. 2014. Transmission of ESBL/AmpCproducing Escherichia coli from broiler chicken farms to surrounding areas. Vet J 172: 519-527.

Leboffe MJ, Pierce BE. 2011. A Photographic Atlas for the Microbiology Laboratory, 4th ed. Morton Publishing Company, New York, USA.

Lukman DW, Sudarwanto MB, Purnawarman T, Latif H, Pisestyani H, Sukmawinata E, Akineden Ö. 2016. CTX-M-1 and CTX-M-55 producing Escherichia coli isolated from broiler feces in poultry slaughterhouse, Bogor, West Java Province. Global Adv Res J Med Med Sci 5: 287-291.

Masruroh CA, Sudarwanto MB, Latif H. 2016. Incidence rate of Escherichia coli producing extended-spectrum beta-lactamase isolated from broiler faeces in Bogor City. Jurnal Sain Veteriner 34: 42-49.

Mehdi Y, Létourneau-Montminy MP, Gaucher ML, Chorfi Y, Suresh G, Rouissi T, Brar SK, Côté C, Ramirez AA, Godbout S. 2018. Use of antibiotics in broiler production: Global impacts and alternatives. Anim Nutr 4: 170-178.

Memish ZA, Balkhy HH, Shibl AM, Barrozo CP, Gray GC. 2004 Streptococcus pneumoniae in Saudi Arabia: Antibiotic resistance and serotypes of recent clinical isolates. Intl J Antimicrob Agents 23: 32 38.

Niasono AB, Latif H, Purnawarman T. 2019. Antibiotic resistance to Escherichia coli bacteria isolated from broiler farms in Subang Regency, West Java. Jurnal Veteriner 20: 187-195.

O'Hara CM. 2005. Manual and automated instrumentation for identification of Enterobacteriaceae and other aerobic Gram-Negative Bacilli. Clin Microbiol Rev 18: 147-162.

OIE. 2015. OIE: Harmonisation of national antimicrobial resistance surveillance and monitoring programmes. Terrestrial Animal Health Code 1-6. www.oie.int

Overdevest I, Willemsen I, Rijnsburger M, Eustace A, Xu L, Hawkey P, Heck M, Savelkoul P, Vandenbroucke-grauls C, Zwaluw K Van Der, Huijsdens X, Kluytmans J. 2011. Genes of Escherichia coli in chicken meat and humans, the Netherlands. Emerg Infect Dis 17: 1216-1222.

Putra AR, Effendi MH, Koesdarto S, Suwarno S, Tyasningsih W, Estoepangestie AT. 2020. Detection of the extended-spectrum $\beta$ lactamase produced by Escherichia coli from dairy cows by using the
Vitek-2 method in Tulungagung regency, Indonesia. Iraqi J Vet Sci 34: 203-207

Putra ARS, Effendi MH, Koesdarto S, Tyasningsih W. 2019. Molecular identification of extended-spectrum beta-lactamase (ESBL) producing Escherichia coli isolated from dairy cows in East Java Province, Indonesia. Indian Vet J 96: 26-30.

Reinthaler FF, Feierl G, Galler H, Haas D, Leitner E, Mascher F, Melkes A, Posch J, Winter I, Zarfel G, Marth E. 2010. ESBL-producing E. coli in Austrian sewage sludge. Water Res 44: 1981-1985.

Saliu BK, Sule IO, Agbabiaka TO. 2012. Comparative study of bacteria in the digestive tracts of chicken reared as free rangers and those reared in poultry. Biol Environ Sci J Tropics 9: 26-39.

Santos LL dos, Moura RA, Aguilar-Ramires P, Castro AP De, Lincopan N. 2013. Current status of extended-spectrum $\beta$-lactamase (ESBL)producing Enterobacteriaceae in animals. In: Méndez-Vilas A (ed.). Microbiology Book Series. Formatex Research Center, Spain.

Savira M. 2014. Validitas metode konvensional modifikasi terhadap metode konvensional dan chromidTM ESBL untuk deteksi bakteribakteri penghasil extended-spectrum beta-lactamases. JIK 2: 81-90.

Seni J, Falgenhauer L, Simeo N, Mirambo MM, Imirzalioglu C, Matee M, Rweyemamu M, Chakraborty T, Mshana SE. 2016. Multiple ESBLproducing Escherichia coli sequence types carrying quinolone and aminoglycoside resistance genes circulating in companion and domestic farm animals in Mwanza, Tanzania, harbor commonly occurring plasmids. Front Microbiol 7: 1-8.

Shoaib M, Kamboh AA, Sajid A, Mughal GA, Leghari RA, Malhi KK, Bughio SUD, Ali A, Alam S, Khan S, Ali S. 2016. Prevalence of extended-spectrum beta-lactamase-producing Enterobacteriaceae in commercial broilers and backyard chickens. Adv Anim Vet Sci 4: 209-214.

Utami ER. 2011. Antibiotics, resistance, and therapeutic rationality. El Hayah 1: 191-198.

WHO. 2017. Stop using antibiotics in healthy animals to prevent the spread of antibiotic resistance. www.who.int

Yusha'u M, Umar, MI. 2016. Phenotypic detection of extended-spectrum beta-lactamases in bacterial isolates from meat products sold within Kaduna Metropolis in Nigeria. Proceeding of International Conference on Biodiversity Society for Indonesian Biodiversity. Sebelas Maret University, Surakarta, 14-16 January 2016. [Indonesian]

Zheng H, Zeng Z, Chen S, Liu Y, Yao Q, Deng Y, Chen X, Lv L, Zhuo C, Chen Z, Liu J. 2012. Prevalence and characterisation of CTX-M betalactamases among Escherichia coli isolates from healthy food animals in China. Intl J Antimicrob Agents 39: 305-310. 